Finisterra, XXXVI, 71, 2001, pp. 141-142

\title{
POLÍTICAS DE DESENVOLVIMENTO EM REGIÕES DESFAVORECIDAS: O CASO DE PORTALEGRE
}

\author{
Luís Miguel Crespo Carvalho ${ }^{1}$
}

Localizado numa das regiões mais pobres e desfavorecidas do nosso país, e logicamente do espaço europeu, o concelho de Portalegre tem sofrido ao longo dos anos um esvaziamento demográfico e uma estagnação económica que urge inverter no mais breve espaço de tempo.

Apesar de ser uma antiga capital de distrito e conseguir, por essa razão, ser um importante pólo aglutinador na região do Alto Alentejo, o concelho não tem sido capaz de se afirmar à escala nacional nem competir em pé de igualdade com os outros pólos regionais (sobretudo Évora) que progressivamente lhe vão retirando protagonismo.

Os benefícios das intervenções dos poderes públicos são, na quase generalidade dos casos, mais acentuados nas regióes mais deprimidas. Neste sentido, nos últimos anos, sobretudo após a entrada do nosso país na União Europeia, a região do Norte Alentejo (e por inerência o concelho de Portalegre), numa tentativa de diminuir as enormes assimetrias existentes, tem sido alvo dos mais diversos apoios e benefícios. Os vários instrumentos e políticas pensados e dirigidos para esta área, desde a Operação Integrada do Norte Alentejano até à Acção de Valorização do Norte Alentejano, conseguiram dotá-la de importantes equipamentos e infra-estruturas de apoio à actividade produtiva, sempre numa óptica de melhoria da qualidade de vida das suas populações.

Uma vez que, actualmente, o concelho já possui a maior parte desses equipamentos e infra-estruturas, torna-se necessário rendibilizá-los, captar e atrair empresas e pessoas e encontrar estratégias capazes de proporcionar um desenvolvimento sustentado e duradouro para Portalegre.

Pelas mais variadas razões e dado que não basta apenas atrair factores de produção exógenos (interessa, igualmente, criar um ambiente favorável à mobilização das potencialidades endógenas, à consolidação e reestruturação dos tecidos socio-produtivos, ao aumento de competitividade externa) é defendida nesta tese ${ }^{2}$, para além de uma forte aposta na captação/atracção de

1 Geógrafo. E-mail: luiscarvalho1974@yahoo.com.br

2 Carvalho, L. M. C. (2000)-Políticas de desenvolvimento em regiões desfavorecidas: o caso de Portalegre. Dissertação de Mestrado em Geografia Humana e Planeamento Regional e Local, apresentada à F.L.U.L., 220 p. pol. 
grandes unidades externas, a criação de pequenas e médias empresas de cariz endógeno nos sectores industrial e turístico.

Convém salvaguardar que, apesar da tese incidir nos sectores industrial e turístico, salientando-se as maiores potencialidades de um ou outro recurso, assume-se que a grande potencialidade do concelho de Portalegre não está neste ou naquele recurso, mas sim na diversidade e no equilíbrio entre eles.

Já há alguns anos que a indústria do concelho possui um peso relevante na economia alentejana, e mesmo nacional. Contudo, as grandes unidades empregadoras aqui localizadas encontram-se dispersas pelo espaço geográfico concelhio, não sendo convenientemente exploradas as sinergias e complementaridades que poderiam surgir com a sua concentração.

A construção da zona industrial, completamente infra-estruturada, com óptimas acessibilidades e com um preço de solo bastante reduzido, aliada à cultura e experiência industrial dos seus recursos humanos permitem perspectivar um futuro risonho para a indústria neste concelho.

No entanto, sabemos como é difícil competir nesta "Aldeia Global», digladiando-se regiões e cidades pelos melhores investimentos. Propõe-se, por essa razão, a institucionalização da Zona de Localização Prioritária de Portalegre, que, mediante uma discriminação positiva do concelho, através da $\begin{array}{lllllllllll}\mathrm{c} & \mathrm{o} & \mathrm{n} & \mathrm{c} & \mathrm{e} & \mathrm{s} & \mathrm{s} & \tilde{\mathrm{a}} & \mathrm{o}\end{array}$ de um conjunto de incentivos / benefícios, poderia atrair para o seu espaço geográfico um considerável número de empresas e pessoas.

A valorização e correcto aproveitamento da qualidade e diversidade de património natural e edificado, existente no concelho, permitem igualmente perspectivar um enorme crescimento da actividade turística nos próximos anos, uma vez que Portalegre poderá apostar em várias formas de turismo em nítida expansão. A própria afirmação e consolidação da Região de Turismo de S. Mamede (da qual Portalegre faz parte), actualmente em curso, trará inegáveis mais-valias para o concelho. Importa é que Portalegre não seja relegada para um papel secundário, dando-se primazia a outros destinos turísticos próximos (Castelo de Vide ou Marvão).

É pois nesta dicotomia indústria/turismo, na diversificação da sua base económica, que Portalegre deverá procurar o seu tão preconizado e esperado desenvolvimento, não apostando num único recurso ou sector, sob pena de determinadas crises conjunturais «deitarem por terra» muitos dos esforços até agora empreendidos. 